\title{
Mediamorfosis Edukasi Informal Online Melalui Platform Digital Sebagai Peluang Bisnis Baru
}

\author{
Endah Fantini a,1,*, Rousdy Safari Tamba ${ }^{\text {b,2 }}$ \\ ${ }^{\text {a }}$ Institut Ilmu Sosial dan Manajemen Stiami \\ ${ }^{\mathrm{b}}$ Institut Ilmu Sosial dan Manajemen Stiami \\ 1 endah_fantini@yahoo.com *; ${ }^{2}$ rous_dy@yahoo.com \\ * corresponding author
}

\section{ARTICLE INFO}

\section{Article History}

Received Desember 2019

Revised Januari 2020

Accepted Februari 2020

\section{Keywords}

Media Convergence, Informal Digital Education, Mediamorphosis.

\begin{abstract}
The existence of digital and online-based technology has supported disruption in society. This also changed the dynamics of the education business to be able to change the development of digitalization which became a milestone in the Industrial Revolution 4.0. The existence of formal education is starting to become popular because today's learning media is very easy to obtain through Video On Demand on the internet. Although now more and more are offering informal education with the virtual learning model. Although not a few, take advantage of this opportunity to provide informal education for new business opportunities. Through Mediamorfosis Theory, here the researchers found that the convergence of informal education has changed the pattern of learning that is related to technical expertise for audiences who have a high level of activity. Besides, this informal study also provides official certificates approved by the institution, so that the potential, business too, formality, informal, and informal.
\end{abstract}

\section{PENDAHULUAN}

Memasuki revolusi industri keempat atau dikenal dengan Revolusi Industri 4.0 yang dibangun di atas Revolusi Digital, mewakili cara-cara baru ketika teknologi menjadi tertanam dalam masyarakat dan bahkan tubuh manusia. Revolusi Industri keempat ditandai dengan munculnya terobosan teknologi di sejumlah bidang, termasuk kecerdasan buatan, nanoteknologi, komputasi kuantum, bioteknologi, Internet of Things dan Big data. Pada tingkat fundamental, industri 4.0 dapat menyatukan dunia digital dan fisik serta menawarkan peluang baru untuk mengumpulkan dan menggunakan informasi. Hal ini berpotensi meningkatkan efisiensi dan mendorong inovasi dalam skala besar.

Internet of Things (IoT) memimpin Revolusi Industri Keempat atau yang dikenal juga sebagai Industri 4.0. Iot memiliki potensi untuk mengubah pemahaman kita tentang bagaimana segala sesuatu dapat terhubung, dan juga memberikan nilai yang sangat besar bagi dunia. Banyak penelitian dunia memperkirakan bahwa pada tahun 2030 IoT memberikan potensi yang sangat besar, untuk itu sektor bisnis juga perlu serius menangani resiko-resiko yang baru akan muncul di era konektivitas. (Savitri, 2019: 65).

IoT juga dapat membentu meningkatkan proses pemeliharaan dan pengawasan. Maintenance prediktif bekerja dengan mengidentifikasi masalah pendidikan secara real time. Termasuk dalam hal pengawasan terhadap proses pendidikan yang dilakukan jarak jauh atau biasa disebut dengan Blended Learning berbasis teknologi digital Online. Sejak kemudahan akses internet di segala sektor industri dan juga bertumbuhnya perusahaan-perusahaan produk dan jasa yang memberikan penawaran akses internet mudah dan online, segala bentuk sistem operasional kerja infrastruktur dan juga institusi pendidikan juga mulai memanfaatkn teknologi digital tersebut untuk mendukung proses pendidikan yang mudah dijangkau dan tidak menganggu aktivitas lainnya.

Pendidikan dan pengajaran berbasis online sudah mulai diterapkan pada perguruan tinggi yang kemudian diikenal dengan pembelajaran e Learning. Bahkan tak sedikit sistem pendidikan dan pengajaran jarak jauh untuk pendidikan formal pun yang mengikutinya terutama bagi para mahasiswa yang tengah bekerja dan waktunya sangat tidak memungkinkan melanjutkan ke studi formal yang mengharuskan untuk pertemuan tatap muka. Disini kemudian memanfaatkan kemajuan teknologi digital, sangat dimungkinkan sistem pendidikan jarak jauh dan tidak perlu diadakan pertemuan tatap muka, meskipun sistem 
pemebalajaran semacam ini juga mendapat kritik karena menghambat interaksi dekat antara guru dan siswanya atau dosen dengan mahasiswanya.

Berkembangnya sistem pendidikan jarak jauh di sistem pendidikan formal seperti di perguruan tinggi ini pun rupanya menjadi inspirasi bagi lembaga-lembaga pendidikan informal yang menawarkan sistem pembelajaran kognitif maupun sistem pembelajaran keahlian jarak jauh yang juga memiliki legalitas belajar serta mengeluarkan sertifikat resmi yang diakui. Hal ini kemudian dijadikan sebagai salah satu peluang usaha bagi para penyedia jasa edukasi yang menawarkan jasa pembejaran untuk pendidikan jarak jauh.

Transformasi pendidikan berbasis digital dengan sistem konektivitas di dalamnya bisa memberikan peluang bisnis bagi lembaa-lembaga pendidikan memanfaatkan peluang sistem pendidikan informal dengan mudah. Seperti halnya pendidikan keahlian seni fotografi, desain grafis, kemudian pembelajaran pajak mulai dari Brevet A dan B, pelajaran sekolah untuk tingkat Dasar dan Menengah, serta jasa pendidikan keahlian lainnya yang semuanya bisa dibuat dalam pendidikan Blended learning.

Pendidikan keahlian kini tidak lagi mengandalkan pertemuan tatap muka langsung di dalam kelas (meskipun masih ada lembaga pendidikan yang masih menerapkan pertemuan secara langsung), namun dalam pendidikan keahlian bisa diterapkan pertemuan yang hanya menggunakan perangkat digital online seperti melalui gadget smartphone, tablet PC, Komputer, Laptop, smart tv, dan lain sebagainya. Adapun dalam perangkat seperti ini tentunya juga didukung dengan platform aplikasi online yang bisa dibuat dan dikembangkan sendiri serta dikelola sendiri dengan ketentuan bahwa pihak yang mengelola aplikasi ini juga harus memahami penggunaan aplikasi itu sendiri dengan keahlian khusus.

Era Revolusi Industri 4.0, keahlian komputer sudah menjadi bagian kecil kewajiban dari para peserta didik yang harus dimiliki, namun di balik itu juga harus berbekal keahlian menggunakan aplikasi online digital dan mahir dalam mengelola aplikasi web internet di Komputer maupun menggunakan aplikasi smartphone. Industrialisasi berbasis digital sudah mengajukan tuntutan lebih kepada generasigenerasi baru maupun generasi lama untuk bisa beradaptasi lebih intens dengan teknologi yang digunakannya.

Pada generasi milenial, tentunya bukan menjadi hal yang asing bila harus beradaptasi dengan perangkat digital dan terkoneksi dengan jaringan online, karena pada generasi ini teknologi sudah berkembang pesat dengan berbasis pada teknologi digital dan kemunculan perangkat-perangkat gadget yang terus mengalami perkembangan pesat dengan penawaran fitur-fitur baru di dalamnya, bahkan dalam hitungan bulan saja, perangkat gadget semacam smartphone atau laptop pun bisa mengeluarkan produk baru yang lebih canggih dengan aplikasi dan fitur-fitur yang lebih lengkap dari sebelumnya. Hal ini pula yang membuat para generasi milenial mudah dan cepat untuk beradaptasi dengan perangkat digital.

Hal ini menunjukkan bahwa teknologi juga mampu untuk memberikan perubahan pada aspek sosial.Teknologi menjanjikan perubahan. Setiap penemuan baru akan melahirkan berbagai perubahan dalam masyarakat. Ibarat sebuah subsistem, kehadiran teknologi baru sebagai subsistem baru dalam masyarakat akan membawa berbagai konsekuensi, subsistem lain dalam sistem tersebut mau tidak mau harus menyesuaikan diri akibat kehadiran teknologi tersebut. Dikatakan oleh talcot Parsons, teknologi pasti akan mengubah pola aktivitas keseharian individu. (Martono, 2016)

Teknologi juga menjanjikan kemudahan. Jelas, teknologi memang diciptakan untuk memberikan kemudahan bagi individu. Orang tidak perlu susah-susah menghubungi sanak keluarganya diluar kota, bahkan diluar negeri, mereka cukup menekan beberapa nomor melalui handphone. Begitu pula dalam hal sarana pembelajaran yang bisa dilakukan di media online digital seperti melalui video yang terkoneksi melalui internet.

Adapun teknologi juga menjanjikan peningkatan produktivitas. Perusahaan besar memanfaatkan banyak teknologi untuk alasan efisiensi dan peningkatan produktivitas daripada harus memperkerjakan tenaga kerja manusia yang memakan banyak anggaran untuk menggaji mereka. Teknologi juga dapat meningkatkan keuntungan perusahaan dengan berlipat ganda. Serta teknologi dapat dimanfaatkan sebagai alat kontrol untuk mengevaluasi kinerja seseorang. (Martono, 2016)

Hal inilah yang kemudian menjadi potens yang memunculkan disrupted society yang dengan kesadaran penuh menciptakan perubahan dan kemajuan melalui cara-cara baru. Hal ini yang tentunya jelas 
menuntut mindset baru:disruptive mindset. Ketika teknologi memasuki gelombang ketiga, Internet of Things, hal ini berarti media sosial dan komersial sudah memasuki titik puncaknya. Dunia kini memasuki gelombang smart device yang mendorong semua hidup dalam karya-karya yang kolaboratif.

Adaptasi terhadap budaya baru dengan kehadiran teknologi digital, serta perangkat-perangkat elektronik digital yang semakin berkembang, hal ini yang kemudian membuat para generasi saat ini, termasuk perubahan masyarakat saat ini yang mengalami perubahan dalam pola penerimaan informasi, cara berkomunikasi, termasuk perubahan dalam menerima edukasi dari luar dan lain sebagainya.

Peran teknologi dalam mempengaruhi perubahan manusia bukanlah sebuah hal yang perlu dipertanyakan lagi. Manusia tidak akan mampu hidup tanpa teknologi. Secara sosiologis, teknologi memiliki makna yang lebih mendalam daripada peralatan. Teknologi menetapkan suatu kerangka bagi kebudayaan non materiil yang dimiliki suatu kelompok. Jika teknologi suatu kelompok mengalami perubahan, maka cara berpikir manusia juga akan mengalami perubahan. Hal ini juga berdampak pada cara mereka berhubungan dengan yang lain.(Henlin dalam Martono, 2016).

Tak dipungkiri bahwa kehadiran teknologi digital berbasis online bisa menjauhkan jarak hubungan berkomunikasi antara satu satu orang dengan orang lainnya, bahkan dalam hal praktek belajar mengajar juga bisa dilakukan jarak jauh sehingga para siswa tidak perlu jauh-jauh datang ke lembaga kursus pendidikan informal, mereka cukup belajar melalui perangkat (device) yang mereka miliki seperti halnya smartphone, tablet PC, ataupun Laptop yang terhubung dengan akses internet dan belajar secara online sehingga tidak menyulitkan bagi pihak siswa untuk tidak beranjak dari tempat tidurnya atau tempat duduknya.

Hal ini tentunya diperlukan infrastruktur yang memadai dari lembaga penyelenggara kursus online untuk bisa memfasilitasi sarana belajar yang mudah dan efektif bagi para siswa didiknya meskipun pada akhirnya kelemahan mendasar yang kerap dialami oleh siswa kursus ini adalah tidak dapat berinteraksi langsung tatap muka dengan mentornya yang kadnag hal ini membuat anak-anak milenial cenderung malas untuk mendatangi tempat kursus dan memilih untuk berdiam diri di dalam rumah atau di cafe bermain dengan perangkat gadget nya.

Remaja saat ini cenderung dimanjakan dengan teknologi, bahkan tidak sedikit yang masih duduk di tingkat SMA hingga perguruan tinggi yang mencari referensi tugasnya melalui internet, seperti mencari melalui artikel-artikel di blog, jurnal dan sebagainya. Termasuk pembelajaran keahlian yang dipelajarinya melalui Video on Demand seperti youtube.

Inovasi pembelajaran yang baru pada pengembangan keahlian melalui pendidikan informmal semacam ini kemudian membuat perubahan dalam pola belajar dan juga pembentukan kebiasaan baru dalam penerimaan pembelajaran bagi siswa didik yang bisa belajar memanfaatkan sarana teknologi digital seperti gadget dan bisa dilakukan dimana saja, serta perubahan pola kebiasaan masyaraka yang pada akhirnya terbiasa dengan pendidikan berbasis online yang praktis dan tidak membuang banyak waktu hal inilah yang menjadi bagian dari janji sebuah teknologi.

Setiap perkembangan teknologi selalu menjanjikan kemudahan, efisiensi, serta peningkatan produktivitas. Memang, pada awalnya teknologi iciptakan untuk mempermudah pekerja manusia dan mempermudah manusia untuk memenuhi segala kebutuhan hidupnya. (Martono, 2016: 217)

Kehadiran media sosial turut menjadi sarana yang mumpuni dalam memfasiltasi kegiatan promosi oleh lembaga-lembaga penyedia jasa edukasi informal atau kursus untuk memasarkan jasa pembelajaran online. Hal ini dinilai efektif lantaran media sosial menjadi bagian dari kehidupan dan gaya hidup masyarakat saat ini. Sehingga diharapkan dengan media sosial ini upaya promosi yang dilakukan oleh lembaga pendidikan tersebut dapat mencapai kuantitas pelanggan yang diharapkan.

Tidak sedikit lembaga-lembaga kursus online yang menawarkan pelatihan dan pembelajaran keahlian melalui media online. Seperti halnya Ruang guru, bahasotalk, dan kelas.com yang menawarkan kursus secara online atau melalui kelas online yang bisa diakses oleh siapapun yang mendaftar. Di setiap pelatihan yang diikuti dan pembelajaran yang diikuti juga diberikan sertifikat resmi lembaga yang bersifat legal. Berdasarkan jumlah permintaan market e-learning setiap tahunnya, yaitu sebesar 25 persen. Lebih besar dari rata-rata di Asia Tenggara sebesar 17,3 persen. Indonesia, Tiongkok, Amerika, India, dan Brasil, memiliki peluang yang menjanjikan di tahun 2017 karena diproyeksi mengalami peningkatan e-learning 
market sejumlah 12,2 miliar dolar AS.Tahun 2019 juga, Indonesia akan menjadi top 5 buyers of mobile learning products and services di seluruh dunia.https://wartakota.tribunnews.com/2017/12/09/indonesiamenempati-urutan-ke-8- untuk-kebutuhan-e-learning

Pembelajaran tanpa harus tatap muka ini yang semakin berjamuran ditawarkan melalui media sosial seperti melalui instagram, Facebook, ataupun Youtube. Alhasil dari promosi yang semakin gencar ini kemudian memudahkan setiap orang untuk mengakses dan semakin banyaknya peserta pelatihan yang mengikuti kursus online jarak jauh, sehingga hal ini sangat mengancam keberadaan tempat-tempat kursus yang sudah lama berdiri untuk pembelajaran tatap muka di dalam kelas dan interaksi antara mentor dengan muridnya. Perusahaan teknologi pemasaran niaga Criteo mencatat, televisi masih menjadi saluran utama untuk beriklan di Indonesia. Namun pertumbuhan iklan melalui media online lebih cepat dibanding televisi. Menurut Criteo, pertumbuhan tahunan gabungan (CAGR) belanja iklan di televisi tumbuh 14,5\% sejak 2014 hingga 2019. Sementara belanja iklan secara online tumbuh 44,3\% untuk periode yang sama.pengguna yang mengakses internet lewat smartphone dan komputer mencapai 39,28\% dari total. Ia memperkirakan, lebih dari $26 \%$ masyarakat yang terpapar internet di Indonesia memiliki lebih dari dua perangkat pada 2022. Dengan begitu, ia memperkirakan $89 \%$ dari total anggaran pemasaran akan diinvestasikan secara online di 2022. Saat ini, ia mencatat $20 \%$ alokasi belanja iklan melalui display berbayar pada 2019. Lalu, sebanyak 15\% mengalokasikan belanja iklan melalui media sosial. Sementara pemasaran tradisional, konten, afiliasi, situs pribadi, search engine optimization (SEO), dan surat elektronik masing-masing 9\%. https://katadata.co.id/berita/2018/11/21/tv-masih-mendominasi-tapi-iklanonline-tumbuh-lebih-cepat.

Pasar digital advertising Indonesia 2019 diprediksi akan tumbuh pesat menurut 2019 Global Digital Ad Trends Report dari PubMatic. Diperkirakan, belanja iklan digital Indonesia akan mencapai \$2,6 miliar (sekitar Rp36,5 triliun) pada tahun ini atau meningkat 26 persen dibanding tahun lalu. Ini adalah angka pertumbuhan tertinggi, mengalahkan negara-negara Eropa seperti Rusia, Irlandia, Swedia, Prancis, Belanda, Italia, dan Swedia.

Total belanja iklan digital Indonesia di 2019 sebenarnya masih kecil bila dibandingkan dengan Amerika dan China dalam laporan PubMatic ini. Kedua negara tersebut adalah satu-satunya pasar dengan pengeluaran iklan digital lebih dari \$10 miliar yang diproyeksikan akan tumbuh pada tingkat dua digit di tahun 2019. Namun, dari sisi persentase pertumbuhan YoY, mereka masih kalah dengan negara berkembang seperti Indonesia dan India. Bila dilihat dari \% YoY change, Indonesia berada di posisi puncak dengan persentase pertumbuhan mencapai 26 persen. Sementara di peringkat kedua ada India (20\%), diikuti oleh Rusia (19\%), Thailand (15\%), dan Meksiko (15\%) yang kelimanya berada di posisi lima teratas, termasuk Indonesia. https://digiads.co.id/blog/news/digital-advertising-indonesia-2019/

Tumbuh suburnya pasar digital advertising Indonesia ini dapat terjadi karena didorong oleh sejumlah faktor. Salah satunya adalah peningkatan pengguna internet yang kini telah melebihi setengah dari total populasi penduduk Indonesia yang berjumlah 265,4 jiwa. Di samping itu, perkembangan fitur beriklan di media sosial dan tren belanjaonline juga ikut mendorong pebisnis untuk mengkampanyekan brand dan promosi ke ranah digital. PubMatic pun mencatat total belanja iklan digital secara global di 2019 diproyeksikan dapat mencapai \$327,28 miliar (sekitar Rp4.601 triliun), tumbuh hingga 48,5 persen. Pun di tahun berikutnya yang diprediksi angkanya dapat mencapai $\$ 380,40$ miliar (sekitar Rp5.346 triliun), atau tumbuh hingga 54,5 persen. Artinya, jika merujuk pada data ini, sampai 2020 sebagian besar belanja iklan akan dikeluarkan untuk periklanan digital dan menggeser perlahan tren iklan konvensional atau tradisional.https://digiads.co.id/blog/news/digital-advertising-indonesia-2019/

Semakin lama tempat kursus konvensional yang memberikan edukasi tatap muka dan interaksi langsung dengan mentor ini semakin kekurangan jumlah siswanya. Hal ini dikarenakana masyarakat yang sudah semakin nyaman dengan teknologi digital dan juga tingkat kesibukan masyarakat yang terlalu tinggi, sehingga tidak lagi memiliki waktu untuk mengikuti kursus tatap muka yang dirasa kebanyakan generasi saat ini terlalu menghamburkan uang dan waktu, sehingga lebih banyak yang memilih kursus online.

Selain efisiensi waktu tanpa harus berangkat ke tempat kursus, serta harga kursus online yang ditawarkan terlalu murah dan daya jual yang rendah untuk kursus-kursus online bila dibandingkan dengan kursus tatap muka yang semakin lama menawarkan harga jasa edukasi yang semakin tinggi mengingat 
tempat kursus pun juga perlu memperhatikan pembiayaan operasional tempat, pajak, biaya operasional lokasi kursus, serta pembiayaan sumber daya manusia (staf dan tenaga pengajar) dan pembiayaan lainnya.

Sementara itu, untuk kursus online sendiri tidak memerlukan pembiayaan yang terlalu mahal karena memanfaatkan sarana web atau media online untuk operasional kerjanya dan juga membayar tenaga pengajar yang bisa lebih diminimalisir di satu sisi generasi saat ini juga lebih nyaman berinteraksi melalui perangkat ponsel smartphone atau perang gadget lainnya dibandingkan harus berinteraksi langsung dengan mentornya, sehinga hal ini cukup mengancam keberadaan tempat kursus yang sudah berdiri lama dan resmi dengan menyediakan tempat secara fisik. Hal ini tentu menjadi iklim kompetitif yang cukup membentang antara penyedia jasa edukasi informal berbasis online dengan edukasi informal dalam lembaga yang cukup mapan keberadaan fisiknya.

Perangkat digital online terus memberikan sarana dan kemudahan dalam belajar serta memberikan penawaran waktu yang efektif dan efisien karena tidak ada ketergantungan pengguna jasa untuk datang dan berinteraksi tatap muka dengan mentornya. Sementara itu menjadi problem market bagi lembagalembaga pendidikan informal dalam mencari murid atau pelanggan sebagai user dari jasa pendidikan yang diberikan dan juga terjadi perbahan pola penggunaan media digital sebagai pembelajaran informal yang mulai ditawarkan pada masyarakat luas. Berdasarkan latar belakang inilah peneliti mengangkat penelitian tentang konvergensi media digital sebagai perangkat edukasi pembelajaran online dan terjadi perubahan pola belajar dan penggunaan perangkat media digital.

Edukasi pembelajaran sudah mulai melakukan konversi sistem pembelajaran menjadi pembelajaran blended learning. Hal ini dilakukan dengan mengintegrasikan perangkat multimedia seperti video, audio, dan teks tutorial yang digunakan secara serentak dalam sekali pembelajaran online. Bahkan tidak ada ketergantungan siswa untuk belajar dengan sebatas teks tertulis seperti buku diktat, namun juga diberikan ilustrasi berupa audio visual yang mendukung serta animasi yang menjadikan siswa lebih mudah paham dalam mempelajari pembelajaran kogntif hingga pembelajaran keahlian.

Pembelajatan dengan jarak jauh dan metode sistem pembelajaran yang memberikan ressensi melalui layar komputer atau smartphone memang bisa terbilang baru, lantaran hal ini juga dilihat dari teknologi blended learning yang belum terlalu familiar sebelumnya.

Hal ini seperti yang dilakukan oleh Ruangguru.com, bahasotalk, dan kelas.com yang mengintegrasikan sistem pembelajaran terpadu dengan sistem integasi multimedia, kemudian juga menggunakan jaringan internet untuk membangun koneksi edukasi antara satu orang dengan orang yang lain, selain itu juga mengkoordinasikan antar pengguna (user) yang tersimpan dalam sistem cloud computing dan terintegrasi pada satu main frame server dari masing-masing edukasi. Untuk sistem pengajaran yang ditawarkah ada yang bersifat satu arah ataupun bersifat dua arah dalam memberian arahan kepada para siswanya. Selain itu juga adanya kerjasama dan kesepakatan antara lembaga pendidikan penyedia sarana jaringan dengan siswa yang secara tidak langsung diwajibkan untuk memiliki perangkat gadget

Dalam penelitian in untuk meneliti proses mediamorfosis dari sistem pembelajaran online untuk edukasi blended learning dan untuk mengetahui bagaimana tahapan ko evolusi, konvergensi, kompleksitas transformasi media pembelajaran online dalam edukasi informal.

\section{KERANGKA TEORITIS}

\section{Computer Mediated Communication (CMC)}

Teori media baru yang saat ini cukup populer digunakan adalah teori Media Komunikasi Komputer (Computer Mediated Communication) yang juga disingkat CMC. Teori ini digunakan sebagai landasan dalam riset komunikasi di media global dengan memanfaatkan media internet. Diantaranya riset dengan pendekatan Netnografi. Pada riset Netnografi meneliti tentang komunikasi dari komunitas Online seperti di media sosial. Teori ini digunakan sebagai landasan dasar dari penjelasan permasalahan komunikasi melalui media online.

Keutamaan Computer Mediated Communication (CMC) pada dasarnya mengacu pada komunikasi manusia yang dicapai melalui, atau dengan bantuan teknologi komputer. Seperti definisi yang diutarakan oleh Gerry Santoro (1995) dalam Thurlow, Lengel dan Tomic (2004). Pada umumnya, 
CMC dapat mencakup hampir semua penggunaan komputer termasuk beragam aplikasi seperti program analisis statistik, sistem penginderaan jarak jauh, dan pemodelan keuangan, semuanya sesuai dengan konsep komunikasi manusia. John December (1997) mendefinisikan Computer Mediated Communication adalah proses komunikasi manusia melalui komputer, melibatkan orang-orang, berada dalam konteks tertentu, terlibat dalam proses membentuk media untuk berbagai keperluan. Sementara Susan Herring (1996) mengatakan bahwa CMC adalah komunikasi yang terjadi antara manusia melalui instrumen komputer. Serta melihat bagaimana para ilmuwan mendefinisikan CMC secara teori, cara lain yang baik untuk mempelajari apa istilah ini adalah dengan melihat publikasi ilmiah untuk melihat apa yang sebenarnya diteliti dan dibahas atas nama CMC.

Beberapa konsep inti pada Teori Computer Mediated Communication ini di antaranya: (Crispin \& Thurlow, 2016)

\section{Komunikasi (Communication)}

CMC dalam memahami prinsip-prinsip dasar komunikasi dengan memulainya pada pemahaman dasarnya yang berkaitan (1) dengan komunikasi manusia daripada media atau komunikasi massa atau teknologi komunikasi, dan (2) interaksi sosial. Di luar ini, mungkin untuk mengklarifikasi posisi kita sedikit lebih jauh dengan serangkaian-serangkaian pernyataan singkat dan saling terkait tentang bagaimana kita memahami sifat komunikasi.

Pada CMC, komunikasi dilihat pada 4 pembagian sifat, diantaranya Komunikasi bersifat dinamis, transaksional, multifungsional, dan multimodal. 176 Pada Komunikasi bersifat dinamis, yaitu komunikasi lebih baik dipahami sebagai proses yang jauh lebih dinamis. Makna pesan tidak ada dalam kata-kata, tapi jauh lebih lancar dan bergantung pada konteks, bergeser terus-menerus dari satu tempat ke tempat lain, dari orang ke orang, dan dari waktu ke waktu.

Komunikasi bersifat transaksional. Meskipun orang terkadang suka memikirkan komunikasi sebagai pertukaran pesan antara pengirim dan penerima, komunikasi benar-benar tentang negosiasi makna antar manusia. Individu baik pembicara dan pendengar dan peran ini berulang-ulang setiap saat dalam percakapan satu sama lain.

Komunikasi bersifat multifungsional. Sadar atau tidak sadar, komunikasi melayani banyak fungsi yang berbeda dan biasanya melayani lebih dari satu fungsi pada waktu tertentu. Misalnya, komunikasi dapat digunakan untuk mempengaruhi perilaku atau atensi orang, memberi tahu orang, mencari informasi, memberikan kontrol atas orang lain, berteman atau merayu orang, untuk menghibur dan menyenangkan orang lain, dan sebagainya. Meskipun demi kenyamanan analitis, para ilmuwan terkadang membedakan antara domain komunikasi interaksional (atau hubungan-fokus) dan informasi (fokus konten), biasanya tidak mungkin memisahkan keduanya.

Komunikasi bersifat Multimodal. Betapapun pentingnya, bahasa ini tentu saja hanyalah salah satu dari banyak cara yang kita miliki untuk berkomunikasi. Pesan verbal selalu dikemas dengan pesan lain (atau 'metamessages') yang dibentuk oleh berbagai cara untuk membuat makna - yang biasa disebut mode komunikasi nonverbal. Sebenarnya, lebih sering daripada bukan mode komunikasi lainnya yang mengandalkan mode verbal lebih dari sekadar.

Masing-masing pernyataan tentang komunikasi ini jelas tumpang tindih dengan yang berikutnya. Komunikasi bersifat transaksional dan karenanya harus dinamis; Begitu juga, karena multimodal itu juga pasti multifungsi, dan seterusnya.

\section{Perantara (Mediated)}

Bergantung pada seberapa banyak kita sudah tahu tentang komunikasi manusia, kemungkinan besar Anda akan tahu bahwa semua komunikasi dimediasi sampai batas tertentu atau lainnya. Pada gilirannya, medium hanyalah proses atau sarana dimana sesuatu ditransmisikan melalui pesannya. Oleh karena itu, komunikasi dimediasi melalui interaksi kita dengan orang-orang dan dengan cara dari sejumlah mode verbal dan nonverbal yang berbeda. Komunikasi tidak akan pernah ada dalam ruang hampa. Dalam kasus CMC, tentu saja, lapisan mediasi material lain yang lebih

banyak ditambahkan, yaitu mediasi teknologi. Pada titik inilah makna umum 
medium kata lain mulai diputar - atau lebih tepatnya media bentuknya jamak sebagai 'sarana yang dengannya berita dan informasi dikomunikasikan'. Sekali lagi, CMC biasanya membatasi pada arti teknologi sebagai mesin yang dirancang, dibangun dan digunakan untuk pertukaran informasi dan komunikasi. Inilah yang biasanya disebut sebagai 'Teknologi Informasi dan Komunikasi (atau TIK) dan membawa kita dengan baik ke konsep inti CMC yang terakhir.

\section{Komputer (Computer)}

Setelah menghadapi kompleksitas istilah 'komunikasi' dan 'dimediasi', mungkin masih belum memberikan penjelasan untuk mengetahui bahwa istilah komputer tidak dapat dianggap biasa. Hampir semua kegiatan baik pekerjaan ataupun pendidikan saat ini melibatkan komputer sebagai perangkat kerja, dan akibatnya, hampir semua hal yang kita lakukan ada pada beberapa cara atau yang dimediasi oleh komputer lain. Terlebih lagi, dengan hal-hal seperti konferensi video, Webcam dan pengenalan suara, perubahan teknologi membawa kita lebih dekat dan lebih dekat dengan jenis komunikasi tatap muka yang pernah kita gunakan selama ini. Dengan cara inilah komputerisasi, yang mendorong begitu banyak bidang kehidupan kita, menjadi semakin tak terlihat.

\section{Mediamorfosis}

Media massa sudah mengalami mediamorfosis yang cukup jauh dari perkembangan yang lama. Banyak pernyataan-pernyataan yang berbicara tentang kelebihan dan kelemahan media di era $70-$ 90 an, kini harus terpatahkan dengan kemunculan media baru.Tak terbayang kalau mesin tik yang sudah ada sebelum abad ke 18 kini tergantikan dengan komputer, telepon konvensional yang tergantikan dengan handphone, kemudian teknologi mobile seperti pager yang mengirimkan pesan tertulis jarak jauh tergantikan oleh handphone yang dapat mengirimkan pesan tertulis tanpa harus berhubungan dulu dengan pihak operator.

Keberadaan internet dapat merubah segalanya bagi media massa. Revolusi informasi pun mau tidak mau harus diterima dan menyesuaikan. Media massa mulai melakukan adaptasi terhadap trend perkembangan media yang digunakan oleh khalayak sebagai acuan pasar. Lahirnya revolusi informasi dengan melihat tuntutan pasar yang menginginkan teknologi yang menawarkan kemudahan efektif dan efisien bahkan bisa menjangkau semua kalangan. Selain itu, kekuatan jaringan internet yang terus mengalami kenaikan daya tangkap sinyal sehingga mampu menjangkau lingkup yang lebih luas dari sebelumnya, akhirnya menuntut masyarakat untuk menjadi teknologi sebagai kebutuhan yang tak berkesudahan. Hampir setiap pelayanan publik (public service) sudah beralih berbasis online untuk efisiensi dan memberikan kemudahan bagi masyarakat. Peralihan teknologi komunikasi dan informasi juga dialami pada dunia pendidikan. Jika terdahulu penggunaan sarana pendidikan atau belajar mengajar secara manual dengan menggunakan perangkat kertas, alat tulis, pertemuan tatap muka, kini dengan diciptakannya e learning pembelajaran bisa dilakukan secara jarak jauh dengan dilakukan secara online. Termasuk sarana bermain anak secara nyata, kini bisa dilakukan dengan berkumpul di dalam desa global dalam dunia maya.

Dalam sejarah peradaban manusia, terjadi beberapa transformasi penting dalam komunikasi yang dalam skala masing-masing tak kalah besar dan transformatif dari yang kita alami sekarang : dari lukisan gua ke bahasa lisan, dari kata-kata tertulis ke mesin cetak, telegraf ke radio, siaran televisi ke TV kabel, dan sekarang internet. Internet bukanlah dikategorikan sebagai media baru, melainkan sebagai teknologi dari saluran komunikasi yang membuka akses secara global secara luas. Media baru seperti media sosial, web portal berita, media streaming, blog, dan lain sebagainya memanfaatkan teknologi internet untuk menjalakan operasionalnya. Tak ayal keberadaan internet pun menjadikan revoluasi informasi yang perlu diasadari oleh semua khalayak.

Ketika teknologi media digital sudah mulai meluas, terkadang tidak selalu mendapat animo masyarakat yang luas. Bisa jadi media tidak bisa diterima secara mudah. Bahkan tak sedikit media yang menjadi permasalahan kontroversial yang berkepanjangan. Keberadaan media sosial dan perangkat aplikasi online mampu menimbulkan kesenjangan negatif antar individu. Di satu sisi, media informasi digital juga menjadi bagian dari kebutuhan yang tak terelakkan.

Hampir setiap hari masyarakat melakukan update informasi karena berbagai hal. Sehingga dalam hal bisnis media bisa jadi menggiurkan ketika melihat fenomena kebutuhan informasi dan komunikasi 
yang semakin tinggi dari khalayak. Terkadang khalayak bukan hanya butuh informasi, tetapi juga memiliki kepentingan untuk menginformasikan apa saja, baik fakta maupun opininya. Kebutuhan untuk menyebarkan informasi ini tidak terpenuhi oleh media umum.

Untuk membuat surat pembaca saja, pemuatannya berlangsung lama. Berhubungan dengan media massa penuh dengan ketidapastian, apakah tulisan yang dikirimkan itu bakal dimuat atau tidak, apakah artikel atau surat pembaca yang dibauatnya itu akan dimuat atau tidak. Kalau pun dimuat terkadang harus menunggu hingga berminggu-minggu atau bahkan beberapa bulan saja. Permasalahan yang dijelaskan di atas, kini bukan lagi menjadi masalah yang rumit. Kehadiran media baru digital memberikan opsi-opsi pemuatan tulisan pembaca yang cepat dan memiliki frekuensi pembaca yang tidak sedikit. Kolom-kolom comment sebagai bagian dari ruang publik yang memberikan ruang bagi pembaca untuk memberikan komen. Hal ini seperti halnya surat pembaca yang dimana disediakan ruang di dunia maya untuk menyampaikan gagasan, kritik atau saran. Peran aktif di komen media macam ini yang kemudian juga dikenal sebagai netizen seperti media sosial lainnya.

Maraknya netizen bisa dikatakan bahwa adanya sebuah tuntutan kebutuhan yang sebelumnya tidak tercapai. Kebutuhan ini tak lain adalah kebebasan mengekspresikan pendapat berupa opini kepada media massa, tetapi karena kendala tertentu, jumlah pengirim dan tulisan yang dimuat tidak seimbang dengan jumlah pengirim tulisan sehingga tidak semua orang memiliki kesempatan yang sama karena media massa sebagai institusi bisnis yang harus melihat aspek-aspek nilai jual sebuah tulisan selain dari aspek kualitas tulisan. Tuntutan macam ini yang kemudian juga memacu pertumbuhan mediamorfosis yang hadir di tengah khalayak luas. Mediamorfosis diharapkan mampu menjawab pemenuhan kebutuhan khalayak untukmenginformaskan fakta atau opininya, dan mendapatkan layanan yang mudah dan tidak berlaku menyimpang. Pada media yang melibatkan peran warga seperti jurnalisme warga bisa dikatakan populer yang dimana media digunakan di seluruh penjuru dunia.

Menurut Roger Fidler, sebagai pencetus dari Teori Mediamorfosis mengatakan bahwa transformasi media komunikasi terjadi sebagai akibat interplay rumit dari kebutuhan-kebutuhan yang dibayangkan, tekanan-tekanan kompetitif dan politis, serta inovasi-inovasi sosial dan teknologi. Di satu sisi, keberadaan mediamorfosis sendiri sebenarnya sudah disadari sendiri oleh pasar dengan melihat bentuk keterasingan individu terhadap teknolgi itu sendiri. Perubahan budaya penggunaan media saat ini tidak seperti meningkatnya pamoritas media cetak. Publik lebih banyak mengasingkan diri dengan penggunaan gadget atau berkutat pada perangkat-perangkat yang dapat memberikan kemudahan. Tak sedikit produk teknologi yang ditawarkan kemudian merubah segala bentuk pola dalam bersikap maupun perilaku komunikasi publik.

Secara garis besar, mediamorfosis menuntut cara berpikir yang terpadu tentang evolusi teknologi media komunikasi yang merupakan sebuah sistem yang saling terkait antara bentuk media komunikasi di masa lalu, masa sekarang dan yang sedang dalam proses kemunculannya. Banyak yang tidak membedakan atau mensalah artikan bahwa mediamorfosis dan konvergensi media adalah dua hal yang sama. Yang perlu ditegaskan bahwa konvergensi media merupakan bagian dari konsep Mediamorfosis. Pada konvergensi media cukup memandang bagaimana spesifikasi media menjadi multi, sementara mediamofosis lebih luas cakupannya kepada pengguna media dari tindakan yang konvensional kemudian berubah menjadi tindakan yang praktis, efisien, efektif dan modern. Sudut pandang penggunaan perangkat pun bisa dikatakan beralih 1800 .

Mediamorfosis mengacu pada prinsip metamorfosis binatang. Perubahan berkesinambungan media massa mengikuti perubahan-perubahan seiring teknologi-teknologi yang ditemukan semakin banyak. Kecepatan penyebaran TV juga menyebabkan perubahan yang signifikan dalam industri surat kabar, majalah dan film. Mediamorfosis bukanlah sekedar teori sebagai cara berpikir yang terpadu tentang evolusi teknologi media komunikasi. Alih-alih mempelajari setiap bentuk secara terpisah, mediamorfosis mendorong kita untuk memahami semua bentuk sebagai bagian dari sebuah sistem yang saling terkait, dan mencatat berbagai kesamaan dan hubungan yang ada antara bentuk-bentuk yang muncul di masa lalu, masa sekarang dan yang akan datang. Sehingga disini terjadilah suatu proses dialektis media yang beriringan dengan perkembangan khalayak luas. Proses dialektis ini melihat tiga perputaran siklus antara kebutuhan, media dan publik yang terus saling terkait dan mengalami perputaran yang tak terputus. Ketika kebutuhan akan kemudahan makin meningkat, upaya untuk 
meningkatkan kemudahan pada kebutuhan pun diimplementasikan meskipun teknologi sendiri tidak selalu menjangkau pemenuhan $100 \%$ kebutuhan publik.

Fidler membagi 3 konsep pada mediamorfosis. Di antaranya, koevolusi, konvergensi, dan kompleksitas. Penjelasan mengenai 3 konsep tersebut, dapat kami gambarkan dalam tabel berikut : (Fidler, 2003)

Tabel 1

Konsep-konsep Mediamorfosis

\begin{tabular}{|l|l|l|}
\hline & Koevolusi & $\begin{array}{l}\text { Perubahan bentuk media komunikasi } \\
\text { merupakan siklus dalam sebuah sistem. Sifat } \\
\text { dasar media selalu tetap menjadi bagian } \\
\text { dalam sistem meski mengalami perubahan. }\end{array}$ \\
\cline { 2 - 4 } MEDIAMORFOSIS & Konvergensi & $\begin{array}{l}\text { Penyatuan berbagai macam teknologi dan } \\
\text { bentuk media yang hadir secara bersamaan. } \\
\text { Mengarah pada bentuk media campuran. } \\
\text { Menghasilkan transformasi atas masing-masing } \\
\text { entitas yang bertemu dan penciptaan entitas } \\
\text { baru. }\end{array}$ \\
\cline { 2 - 3 } & KOmpleksitas & $\begin{array}{l}\text { Situasi dan kondisi yang memaksa terjadinya } \\
\text { perubahan. } \\
\text { Suatu keadaan yang memunculkan gagasan - } \\
\text { gagasan baru yang mentransformasikan dan } \\
\text { menghidupkan sistem-sistem }\end{array}$ \\
\hline
\end{tabular}

Media baru tidak saja telah menjembatani perbedaan pada beberapa media, tetapi juga perbedaan antara batasan kegiatan komunikasi pribadi dengan batasan kegiatan komunikasi publik. Bahan dan kegunaan media semacam itu dapat dipakai secara bergantian untuk kepentingan pribadi dan publik. Di masa mendatang kenyataan tersebut memberikan pengaruh bukan saja terhadap batasan media yang berbeda, tetapi juga terhadap batasan peran institusi media. Mc Luhan menyatakan, ketika teknologi media berekspansi: dari oral ke komunikasi cetak, dari cetak ke penyiaran dan kemudian muncul internet, media digital dan kovergensi media, maka sejak itu muncullah suatu global village yang memungkinkan orang-orang berkomunikasi, bahkan beraktivitas melampaui kemampuan teknologi media sebelumnya. Perkembangan teknologi membawa dampak munculnya komunikasi virtual yang memungkinkan orang-orang di dalamnya tidak sekedar berkomunikasi dalam suatu komunikasi global yang instan, namun mereka dapat mengorganisir dan mengelola content melalui hyperlinks dan search engines melalui the World Wide Web. Walaupun pada tahap awal perkembangannya, media baru dipandang sebagai pengembangan media audiovisual yang sudah ada sebelumnya, namun media baru tetap merupakan tantangan bagi produksi, distribusi, dan bentuk dasar media audiovisual. Keruntuhan media konvensional (seperti dijelaskan sebelumnya) tak lepas sebagai wujud revolusi informasi yang dilihat dari sisi produksi, distribusi dan bentuk yang mengalami perkembangan adalah untuk memberikan kemudahan akses publik melalui media. (Fidler, 2003).

\section{METODE PENELITIAN}

Metode dalam penelitian ini menggunakan metode penelitian Kualitatif dengan pendekatan Netnografi dan paradigma yang digunakan adalah paradigma konstruktivis. Locus pada penelitian ini dilakukan di Jakarta dengan fokus objek penelitiannya adalah lembaga-lembaga start up penyedia jasa edukasi informal untuk pembelajaran online jarak jauh serta mencakup lemaga jasa pengembangan kompetensi pendidikan akademik dan keahlian. Objek yang diteliti terdapat tiga lembaga edukasi informal yaitu ruangguru.com, bahaso.com, dan kelas.com.

"Netnography," atau etnografi pada Internet, merupakan penelitian metodologi kualitatif baru yang menyesuaikan teknik penelitian etnografis untuk mempelajari budaya dan masyarakat yang muncul melalui komunikasi yang dimediasi oleh komputer. Riset semacam ini juga digunakan sebagai teknik riset pemasaran, "netnography" menggunakan informasi publik yang tersedia di forum online untuk mengidentifikasi dan memahami kebutuhan dan pengaruh keputusan kelompok konsumen online yang relevan. 
Dibandingkan dengan etnografi tradisional dan berorientasi pasar, "netnography" jauh kurang mengkonsumsi waktu dan rumit. Berbeda lagi dengan etnografi tradisional dan berorientasi pasar adalah bahwa "netnography" mampu untuk dilakukan dengan cara yang sepenuhnya tidak mengganggu (meskipun opsional yang tidak diperlukan). Pada pendekatan ini terlihat bahwa spektrum keterlibatan secara online terkait masyarakat yang berkisar dari membaca pesan secara teratur dan secara real time membalas anggota lain melalui e-mail atau media compose lainnya. Selain itu dapat mengamati juga komunikasi satu per satu, menawarkan komentar singkat, menawarkan komentar panjang, bergabung dan memberikan kontribusi untuk kegiatan masyarakat, untuk menjadi penyelenggara, ahli, atau suara yang diakui masyarakat. (Kozinets, 2010)

Pemilihan ketiga objek ini yang memberikan fasilitas pembelajan jarak jauh yang tidak hanya diakses dari komputer, namun juga dapat diakses melalui perangkat gadget seperti melalui smartphone atau melalui tablet PC. Selain itu juga dari ketiga lembaga ini memberikan sertifikat legal dan berbadan hukum serta pengguna dari ketiga jasa ini yang cukup banyak dan memiliki banyak peminat sehingga dari ketiga objek yang diteliti memiliki potensi terhadap perubahan pembelajaran dengan cara blended learning online.

Teknik pengumpulan data yang dilakukan adalah melakukan observasi virtual online secara non partisipan dengan menelusuri proses pembelajaran jarak jauh yang dilakukan oleh ruangguru.com, bahaso.com, dan kelas.com yang diamati berdasarkan dari komentar dari para pengguna jasa atau muridmurid dari lembaga edukasi online tersebut, kemudian juga untuk meneliti bagaimana pola interaksi dalam proses belajar mengajar di media online dan pola membangun kontak antar user ataupun antar user dengan mentor. Selain tu juga bagaimana komputer atau aplikasi melalui perangkat gadget berfungsi menjadi mediator dalam interaksi belajar mengajar online.

Pengumpulan data berikutnya adalah dilakukan wawancara secara terstruktur dengan mentor kemudian dengan user (pengguna layanan edukasi informal) dari masing-masing dari ketiga lembaga edukasi informal yang diteliti, dan juga para pengguna atau peserta yang tergabung dalam edukasi informal tersebut.

Analisis data kualitatif yang dilakukan dengan model analisis alir dari Miles dan Huberman yaitu dilakukan denga 3 tahap, yaitu reduksi data, penyajian data dan penarikan kesimpulan. Proses ini berlangsung terus menerus selama penelitian berlangsung, bahkan sebelum data benar-benar terkumpul. Penelitian ini menggunakan teknis analisis data dengan istilah interactive model dari Miles dan Huberman. (Salam, 2006)

Reduksi data merupakan salah satu dari teknik analisis data kualitatif. Reduksi data adalah bentuk analisis yang menajamkan, menggolongkan, mengarahkan, membuang yang tidak perlu dan mengorganisasi data sedemikian rupa sehingga kesimpulan akhir dapat diambil.

Langkah kedua adalah penyajian data merupakan salah satu dari teknik analisis data kualitatif, penyajian data adalah kegiatan ketika kesimpulan informasi disusun, sehingga memberikan kemungkinan akan adanya penarikan kesimpulan. Bentuk penyajian data kualitatif berupa teks naratif (berbentuk catatan lapangan), matriks, grafik, jaringan dan bagan. Pada penyajian data ini juga dibahas dalam bentuk diskusi dari perspektif teori maupun konsep-konsep yang digunakan dalam penelitian ini.

Setelah melalui reduksi data dan penyajian data, maka berikutnya adalah penarikan kesimpulan merupakan salah satu dari teknik analisis data kualitatif. Penarikan kesimpulan adalah hasil analisis yang dapat digunakan untuk mengambil tindakan dan juga untuk langkah awal sebagai rekomendasi dalam pengembangan teori atau konsep melalui implikasi praktis dan implikasi teoritisnya. (Creswell, 2009)

\section{HASIL DAN DISKUSI}

Berdasarkan hasil penelitian dari ketiga lembaga bimbingan belajar online ini terlihat bahwa sistem pembelajaran online dilakukan dengan pembelajaran satu arah dan dua arah. Pada pembelajaran satu arah, para peserta didik yang tergabung dalam situs web media belajar online ini mengharuskan setiap peserta atau murid yang tergabung dalam web lembaga bimbingan belajar online ini untuk menjadi member dengan membuat akun terlebih dahulu di awal sebelum masuk pada proses pembelajaran. 
Anggota member ini harus sudah terdaftar sebelum peserta melakukan transaksi lebih lanjut. Setelah itu pada pemilik akun diberikan arahan dan prosedur dalam mengikuti pembimbingan belajar dan kursus online di media pembelajaran ruangguru, bahaso, dan kelas.com. Para peserta diwajibkan untuk memiliki perangkat gadget seperti smartphone, tabel, laptop, pc dan sebagainya untuk bisa mengikuti pembelajaran online yang dipandu oleh mentor-mentor yang ahli dibidangnya dan dipandu selama pembelajaran. Adapun setiap peserta juga diberikan modul, pengarah langsung dari mentor dalam bentuk video tutorial dari guru atau mentor pengajar dan ada yang dalam bentuk rekaman mentor mengajar, kemudian ada juga yang hanya berupa suara seperti halnya bahaso yang dapat mengajarkan peserta melalui suara tutorial.

Pada media pembelajaran ruang guru online, sistem pembelajaran bisa dilakukan dengan tutorial suara dan visual vector dan juga menampilkan video mentor atau guru yang direkam dan ditampilkan di dalam web sesuai dengan menu yang dipilih oleh user. Pola interaksi yang dibangun bersifat satu arah yang dimana bimbingan kursus online menampilkan pesan-pesan dalam bentuk audio maupun visual yang dapat diterima oleh pengguna. Disitu para user bisa mendengarkan sekaligus melihat proses pengajaran melalui perangkat gadget secara online dan mudah serta tidak terbatasi oleh waktu.

Kontak dan komunikasi antara pengajaran dan murid sama-sama termediasi oleh komputer dan tidak terlibat kontak secara langsung. Sehingga disni pengajaran dilakukan seefisien mungkin meminimalisir pertemuan langsung dengan mentor yang hanya cukup melalui video interaktional yang memungkinkan bagi anak-anak mudah untuk belajar selain diiringi dengan visual-visual menarik dan logika pembelajaran yang mudah dipahami seperti halnya dalam pembelajaran kursus. Melalui web ini pun para peserta juga diberikan kesempatan untuk berkomunikasi dan berinteraksi langsung dengan mentor melalui chatting untuk memudahkan dalam berkomunikasi secara praktis tanpa menggunakan perangkat tambahan.

Model blended learning yang ditawarkan oleh ruang guru ini beragam, mulai dari pembelajara visual yaitu pembelajaran melalui modul yang berisikan teks-teks tertulis yang ditampilkan pada layar komputer atau gadget, kemudian siswa dapat memilih pembelajaran yang disukai menurut bidang mata pelajaran yang ingin dipelajari, kemudian juga pembelajaran melalui video interaktif tutorial dengan animasi bergerak serta visual guru atau personal yang direkam sedang mengajarkan suatu mata pelajaran dan ditampilkan melalui layar dalam bentuk rekaman video. Bahasa yang digunakan untuk berkomunikasipun menggunakan bahasa yang formal. Sementara itu juga tercipta interaksi dengan guru yang berangkutan melalui chatting ataupun melalui video call dan bahasa yang digunakan dalam interaksi mentor dengan anak didiknya terlihat sebagai bahasa yang formal dan menggunakan simbol-simbol bahasa yang efektif yang juga didukung dengan perangkat komputer.

Sedangkan pada media pembelajaran pada media bahaso atau lembaga bimbingan bahasa inggris dilakukan diawal dengan cara trial pratice berbahasa inggris dengan mentor yang mahir berbahasa inggris melalui suara atau by call. Hal ini untuk menguji peserta didik yang ikut dalam pembelajaran online berbahasa inggris melalui bahaso tersebut dan juga mengukur tingkat kemampuan berbahasa inggrisnya. Kemampuan berbahasa inggris yang diuji melalui tes awal yang berkomunikasi langsung dengan mentor.

Pola interaksi yang dibangun antara mentor dengan murid dilakukan juga dengan termediasi melalui komputer. Hal ini melihat lembaga bimbingan online seperti bahaso juga memanfaatkan fasilitas digital untuk bisa menampilkan pembimbingan secara terpadu melalui visual vector serta modul elektronik seperti dalam bentuk Ebook yang juga termuat modul di dalamnya dan juga memuat suara untuk pembelajaran secara online seperti halnya pembelajaran video-video tutorial atau melalui video interaktif. Pembelajaran pada dasarnya lebih pda pengamatan yang dilakukan oleh peserta didik, namun dalam interaksi pun juga dilakukan sebagai bagian dari sarana yang disediakan.

Selain itu pada lembaga pendidikan bahasa inggris online, bahaso juga mengadakan pembelajaran virtual dengan audio learning, sehingga model pembelajaran blended learning yang dilakukan oleh bahaso talk ini mudah untuk dipelajari. Tingkatan bahasa inggris yang dipelajar melalui Bahaso ini beragam dengan layanan akses 24 jam belajar, mulai dari pembelajaran untuk tingkat dasar sampai tingkat menengah atas. Kemudian juga untuk tingkat menengah sampai pada tingkat profesional, dan juga kelas khusus secara online untuk pembimbingan khusus program TOEFL dan sejenisnya. 
Model interaksi antara mentor dengan peserta didik yaitu dengan interaksi melalui media chatting atau berkomunikasi langsung secara audio dengan mentor. Sehingga hal ini lah yang memudahkan para peserta didik untuk berkomunikasi dengan mentornya tanpa harus melalui tatap muka. Tentunya agar proses belajar mengajar ini dapat berjalan dengan lancar, diperlukan maintenance (pemeliharaan perangkat) mulai dari perangkat keras (hardware) sampai pada perangkat lunak (software) diperlukan pemeliharaan sarana yang memadai serta diperlukan tenaga-tenaga teknis pengembangan software dan juga pengelolaan aplikasi secara profesional.

Para peserta didik pada umumnya adalah dari kalangan akademik, kemudian juga ada yang guru dan juga kalangan pekerja yang mencari sarana belajar untuk pengembangan keahlian dan keterampilan. Hal ini yang tentunya diperlukan bagi para mentor untuk lebih memperhatikan anak didiknya dan juga menjaga kualitas kompetensinya agar dapat menarik perhatian bagi peserta didiknya. Tentunya pemilihan para mentor untuk lembaga kurusus online ini pun juga merupakan orang-orang yang berpengalaman dan terpilih dalam mengajarakan cara-cara atau model pembelajaran yang variatif dan mudah dipahami oleh para peserta didiknya.

Setiap lembaga pendidikan kurusus online ini berupaya untuk meminimalisir sanksi pada peserta didik lantaran menganggap bahwa para peserta didik di kursus online ini merupakan para siswa/I yang memang mendaftar karena memerlukan pengajaran keahlian dan pembentukan keahian khusus. Sehingga dalam hal berkomunikasi langsung dengan para peserta didik ini pun dilakukan dengan memperhatikan segment peserta mulai dari segment usia, segment jenis kelamin, hingga tingkat pendidikan oleh para mentor.

Dalam menjaga komunikasi ini para mentor pun berupaya untuk mendorong para peserta didik agar lebih aktif dan lebih banyak menyajikan simulasi pengajaran dalam bentuk visual, mengingat segment usia yang banyak diikuti dari para peserta didik ini mayoritas diikuti oleh kalangan remaja atau anak-anak muda baik yang masih menempuh pendidikan ataupun sudah masuk kalangan pekerja.

Selain ruang guru dan bahaso, adapula aplikasi web kelas.com yang juga memprioritaskan pada pembimbingan dan pengajaran keahlian teknis untuk beragam keahlian yang ditawarkannya mulai dari keahlian fotografi, menulis skenario film, keahlian memasak, self make up, keahlian bermusik, olahraga dan lain sebagainya. Segment pada aplikasi ini tentu berbeda dengan ruang guru yang memfokuskan pada kepentingan akademik, bahaso yang menitik beratkan pada segemnt pembelajaran khusus berbahasa inggris, sedangkan kelas.com lebih kepada keahlian dalam keterampilan seni dan keterampilan diri diluar akademik seperti pengembangan bakat, passion, dan hobi.

Pada kelas.com ini lebih menekankan pada keahlian art atau seni dalam berbagai bidang yang langsung dimentorin oleh mentor-mentor ahli ternama atau orang-orang yang terkenal di bidangnya termasuk selebritis yang memiliki keahlian dan kompetensi khusus, selain itu juga chapter pembelajaran ini variasi yang diberikan kepada para peserta yang menginginkan pembelajaran online melalui aplikasi atau web ini dapat membayar sejumlah sebesar Rp.250.000,- per kelas untuk bidang keahlian yang dipilih.

Sistem pembelajaran pada kelas.com semacam ini lebih menekankan pada satu arah atau penyampaian pesan yang langsung dilakukan oleh mentor melalui video tutorial yang merekam langsung mentor ahli tersebut dalam memberikan materi pembelajaran yang setiap materi tersebut bervariasi. Ada mentor yang hanya memberikan 18 video materi pembelajaran saja, kemudian adapula yang memberikan materi hingga 30 video materi pembelajaran. Tidak semua mentor memberikan jumlah video materi dalam jumlah yang sama.

Sehingga melalui kelas.com ini tentunya para peserta tidak bisa berinteraksi langsung dengan mentor yang bersangkutan dan hanya memberikan materi-materi pembelajaran dan juga sertifikat online secara legal. Hal ini tentunya menghambat prosees interaksi dua arah antara mentor tersebut dengan peserta yang mengikutinya. Dalam proses pembelajaran yang diberikan melalui program aplikasi edukasi informal ini, tentunya bersifat praktis dengan bahasa yang mudah dipahamai dan tidak bertele-tele serta para mentor ternama itupun juga membeirkan nilai jual bagi aplikasi sehingga menjadi sarana edukasi bagi para peserta yang mengikutinya secara efisien namun kurang memberikan interaksi langsung dengan mentor. 
Bentuk penyampaian satu arah ini pun tetap termediasi melalui komputer sehingga bentuk pesan yang diberikan dalam video tutorial ini juga bersifat eksklusif dan materi yang diajarkan dalam sekian jumlah materi yang diberikan dan hanya dapat dilihat mealui aplikasi yang bersangkutan, upaya untuk pemahaman yang dilakukan oleh para peserta pun harus benar-benar diberikan pemahaman praktis pada kompetensi keahlian yang sesuai.

Apabila dikaji dalam teori mediamorfosis, koevolusi yang terjadi pada pembelajaran edukasi informal mengalami perubahan dalam proses pembelajaran tatap muka menjadi pembelajaran online yang dimana para peserta kursus cukup belajar melalui perangkat gadget yang dimiliki dan belajar melalui aplikasi perangkat yang terhubung secara online dan bisa diakses dimanapun dalam akses 24 jam. Selain itu juga memudahkan dan efektif waktu bagi para peserta, selain itu juga efisien dari penggunaan waktu belajar hingga efisiensi pembiayaan yang dikeluarkan peserta untuk kursus. Biasanya para peserta kursus mengeluarkan biaya yang cukup besar untuk pertemuan kurusus tatap muka lantaran biaya operasional kurusus yang juga besar, namun dengan adanya pembelajaran online ini pembiayaan kursus kemudian menjadi lebih murah dari segi operasionalnya. Selain itu tidak menyulitkan bagi pengguna fasilitas dalam mengoperasionalkan aplikasi yang digunakan.

Bentuk konvergensi dalam pembelajaran edukasi informal ini merupakan integrasi penyatuan perangkat multimedia yang menggabungkan teks tertulis, video (visual), dan audio untuk proses pembelajaran pada aplikasi. Sehingga hal ini justru memudahkan bagi para peserta yang mengikuti kursus tersebut untuk menampilkan beragam varian visual dan kombinasi teks agar lebih mudah dipahami oleh peserta mulai dari peserta awam maupun peserta yang sudah berpengalaman. Visualisasi tersebut tentunya memerlukan sarana prasarana internet yang mumpuni untuk bisa mereaksikan perangkat multimedia.

Begitu pula dalam interaksi pun juga diperlukan perangkat multimedia yang memadai untuk bisa berinteraksi dengan mentor sepeti menggunakan perangkat seperti web cam ataupun perangkat kamera yang memadai dan kompatibel dengan perangkat yang digunakan. Sehingga hal ini lah konvergensi media tersebut mengalami tranformsi pembelajaran yang sesuai dan tidak mengurangi kaidah pembelajaran yang sebagaimana mestinya dan hanya terdapat perubahan pola dalam interaksi.

Komplektitas yang terjadi di dalam interaksi antara user (pengguna) dengan mentor atau interaksi dalam proses pembelajaran. Disinipun terjadi pemetaan peserta yang tergolong dalam peserta yang pasif atau mingles atau hanya sebatas berbicara namun tidak aktif, adapula peserta yang tergolong toursists atau hanya sekedar mengamati saja proses pembelajaran dan ada juga yang tergolong aktif dalam berinteraksi dengan mentornya. Kompleksitas sistem yang ada pada proses edukasi informal ini pun lebih banyak mengandalkan kehandalan perangkat, sehingga bentuk komunikasi pun terbatas terutama pada proses edukasi satu arah. Dalam hal ini pun berlaku aturan-aturan dalam mengikuti pembelajaran dan keabsahan proses belajar.

Dalam proses belajar semacam ini yang ditujukan pada millenials yang sangat mungkin mempercepat proses mencapai Citizen 4.0. Karena dibesarkan seiring dengan perkembangan internet, mereka telah terbiasa mengakses informasi dari berbagai sumber dan wilayah lain. Millenials cenderung lebih cepat tersadar untuk memperhatikan lingkunan sekitarnya, terlebih lagi dengan semakin banyaknya tokoh masyarakat yang melakukan kegiatan positif menjadi pemberitaan.

\section{KESIMPULAN}

Berdasarkan hasil penelitian maka dapat disimpulkan sebagai berikut:

1. Mediamorfosis pada proses pembelajaran edukasi informal online lebih mengedepankan efisiensi dan efektifitas pembelajaran melalui proses pembelajaran yang tidak menggunakan pembelajaran tatap muka secara langsung, namun lebih mengedepankan pertemuan pembelajaran yang termediasi melalui komputer. Adapun dalam koevolusi pada pembelajaran online melalui aplikasi web yang terkoneksi melalui internet dan dapat digunakan melalui perangkat gadget seperti smartphone, tablet PC, laptop maupun komputer. Sehingga dalam hal ini memudahkan setiap peserta yang terdaftar di dalamnya untuk terkoneksi selama 24 jam akses dan bisa digunakan media pembelajarannya kapan saja. Selain itu juga tidak mengharuskan bagi para peserta untuk bertemu langsung dengan mentor tatap muka, atau harus datang ke lokasi tempat kursus karena dimudahkan dengan perangkat digital. Kompleksitas 
dalam berinteraksi pun juga terjadi seperti halnya audiens yang tergolong dalam toursis atau hanya peserta yang sekedar mendengarkan saja, peserta yang hanya sebatas

2. Konvergensi yang terjadi pada edukasi informal ini juga merupakan intergrasi perangkat multimedia melalui video interaktif mentor yang ditujukan kepada peserta didik, dan juga mentoring melalui sarana audio, dan melalui presentasi teks yang bisa diiringi suara. Sehingga hal ini memerlukan perangkat digital yang memadai. Bentuk komunikasi yang termediasi melalui perangkat digital yang serba tersaranai dengan koneksi internet yang dengan bandwith yang diperlukan juga tinggi. Bentuk intergrasi semacam ini sangat memungkinkan terjadinya perubahan pola interaksi yang sangat memudahkan setiap orang dan hanya memerlukan pembiayaan kurusus yang sangat murah karena tidak terlalu terbebani dengan biaya operasional.

\section{DAFTAR PUSTAKA}

Bungin, Burhan. 2018. Metode Penelitian Kualitatif. Jakarta: Kencana Prenada Media Group.

Creswell, John.W,. 2016. Research Design. Yogyakarta: Pustaka Pelajar.

Creswell, John.W,. 2010. Desain Penelitian Kualitatif (Lima Pendekatan). Yogyakarta: Pustaka Pelajar.

Fidler, Roger. 2003. Mediamorfosis. Yogyakarta: Penerbit Bentang.

Kartajaya, Hermawan. 2019. Citizen 4.0 (Menjejakkan Prinsip-prinsip Pemasaran Humanis di Era Digital). Jakarta: Gramedia Pustaka Utama.

Kasali, Rhenald. 2019. Disruption. Jakarta: Gramedia Pustaka Utama

Kozinets. 2010. Netnography. New York: Sage Publications.

Martono, Nanang. 2016. Sosiologi Perubahan: Perspektif Klasik, Modern, Posmodern, dan Poskolonial. Jakarta: Rajawali Press.

Salim, Agus. 2006. Teori \& Paradigma Penelitian osial. Yogyakarta: Yogyakarta: Tiarawacana.

Savitri, Astrid. 2019. Revolusi Industri 4.0. Jakarta: Penerbit Mizan.

Thurlow, Chrispin, Lengel dan Tomic. 2004. Computer Mediated Communications. London: Sage Publications. 